\title{
Penerapan Model Pembelajaran Problem Based Learning untuk Meningkatkan Hasil Belajar Fisika Materi Suhu dan Kalor
}

\section{Nyoman Sudiarta*}

SMA Negeri 1 Ubud

\section{A R T I C L E I N F O}

Article history:

Received 19 August 2019

Received in revised form

30 September 20189

Accepted 10 October 2019

Available online 30

November 2019

\section{Kata Kunci:}

model pembelajaran

Problem Based Learning

(PBL), hasil belajar fisika.

Keywords:

Problem Based Learning

(PBL) learning model,

physics learning outcomes.

\begin{abstract}
A B S T RAK
Pelaksanaan Penelitian Tindakan Kelas ini diawali dengan pengamatan yang dilakukan Peneliti terhadap hasil belajar siswa kelas XI MIPA 2 pada semester ganjil tahun pelajaran 2017/2018 terhadap mata pelajaran fisika tentang suhu dan kalor masih dibawah rata-rata, dan tingkat ketuntasan siswa belum mencapai standar nilai sesuai yang diharapkan. Penelitian Tindakan Kelas ini dilakukan di SMA Negeri 1 Ubud dengan subjek 35 orang siswa kelas XI MIPA 2 Semester Ganjil tahun pelajaran 2017/2018. Tujuan utama dalam penelitian ini yaitu: untuk mengetahui peningkatan hasil belajar fisika siswa kelas XI MIPA 2 SMA Negeri 1 Ubud. Penelitian ini dilakukan dengan menggunakan tindakan (action research) atau siklus sebanyak dua siklus, dimana setiap siklusterdiri dari empat tahap yaitu: 1) Rancangan (Planning), 2) Pelaksanaan kegiatan dan Pengamatan (Acting), 3) Observasi (Observing), dan 4) Refleksi (Reflecting). Berdasarkan penelitian yang telah dilakukan didapatkan bahwa: 1) hasil belajar fisika siklus I adalah 79 dan 2) hasil belajar fisika siklus II adalah 82. Berdasarkan data penelitian dan pembahasan dapat diambil kesimpulan bahwa dengan diterapkannya model pembelajaran Problem Based Learning (PBL) terbukti dapat meningkatkan hasil belajar fisika bagi siswa kelas XI MIPA 2 SMA Negeri 1 Ubud tahun pelajaran 2017/2018 dengan baik.
\end{abstract}

A B S T R A C T

The implementation of this Classroom Action Research begins with observations made by the Researchers on the learning outcomes of students of Class XI MIPA 2 in the odd semester of the academic year 2017/2018 on physics subject about temperature and heat is still below average, and the level of completeness of students has not reached the appropriate standard values which is expected. This Classroom Action Research was conducted at SMA Negeri 1 Ubud with the subject of 35 students of Class XI MIPA 2 Odd Semester 2017/2018 school year. The main objectives in this study are: to find out the increase in physics learning outcomes of students of class XI MIPA 2 in SMA Negeri 1 Ubud This research was conducted using action or a cycle of two cycles, where each cycle consists of four stages, namely: 1) Design, 2) Implementation of activities and Observation, 3) Observation, and 4 ) Reflection. Based on the research that has been done, it was found that: 1) physics learning outcomes in cycle I was 79 and 2) physics learning outcomes in cycle II was 82. Based on research data and discussion, it can be concluded that the application of Problem Based Learning (PBL) learning model has been proven to be able to improve physics learning outcomes for students of Class XI MIPA 2 in SMA Negeri 1 Ubud in the academic year 2017/2018 well. 


\section{Pendahuluan}

Banyak siswa yang beranggapan bahwa mata pelajaran fisika merupakan salah satu pelajaran yang sulit, rumit dan penuh dengan rumus-rumus. Hal ini juga menyimak atas pernyataan Wiseman (1981) yang menyatakan pendapatnya bahwa ilmu fisika merupakan salah satu pelajaran yang mempunyai tingkat kesulitan tinggi bagi kebanyakan siswa menengah, kesulitan mempelajari ilmu fisika itu terkait dengan ciri-ciri ilmu fisika itu sendiri. Jika siswa tersebut tidak memiliki potensi yang baik dalam bidang fisika, maka siswa tersebut mengalami kesulitan dalam belajar mata pelajaran fisika.

Menurut Nafiah (2014) Model pembelajaran PBL adalah salah satu model pembelajaran yang dapat menyediakan lingkungan belajar yang mendukung berpikir kritis. PBL didasarkan pada situasi bermasalah dan membingungkan sehingga akan membangkitkan rasa ingin tahu siswa sehingga siswa tertarik untuk menyelidiki permasalahan tersebut. Pada saat siswa melakukan penyelidikan, maka siswa menggunakan tahapan berpikir kritis untuk menyelidiki masalah, menganalisa berdasarkan bukti dan mengambil keputusan berdasarkan hasil penyelidikan. Menurut Shofiyah (2018) Proses pembelajaran PBL secara utuh dimulai dengan membagi siswa kedalam grup yang berisi 5-8 siswa, kemudian mereka diberikan masalah. Masalah tersebut harus otentik yang dekat dengan kehidupan sehari-hari. Siswa berusaha memecahkannnya dengan pengetahuan yang mereka miliki, dan sekaligus mencari informasi informasi baru yang relevan untuk solusinya. Mereka harus mengidentifikasi masalah tersebut, kemudian membuat hipotesis, mendaftar apa yang mereka perlukan dan mengeksplor kegiatan eksperimen apa yang mereka butuhkan. Selama dalam kegiatan kerja kelompok tersebut, siswa harus menyelesaikan tugasnya. Mereka harus mengumpulkan informasi sebanyak mungkin dari berbagai sumber. Setelah itu, mereka harus membuat laporan, dan kemudian mempresentasikan kepada teman-teman yang lain. Jika ada masukan atau revisi, mereka harus memperbaikinya dan terakhir yaitu membuat kesimpulan apakah hipotesisi yang telah mereka buat dirterima tau ditolak. Menurut Fakhriyah (2014) PBL mempersiapkan peserta didik untuk berfikir kritis dan analistis dan untuk mencari serta menggunakan sumber pembelajaran yang sesuai. Menurut Firmansyah dkk. (2015) mengatakan bahwa PBL merupakan model pembelajaran yang memberikan kesempatan peserta didik menggali pengalaman autentik sehingga mendorong mereka aktif belajar, mengkonstruksi pengetahuan, dan mengintegrasikan konteks belajar di sekolah dan kehidupan nyata secara ilmiah. Peserta didik tidak sekedar mendengarkan, mencatat, dan menghafal materi yang disampaikan oleh guru, tetapi diharapkan mampu berfikir, mencari, mengolah data, dan berkomunikasi dalam proses pembelajaran. Menurut Susilo dkk. (2012) mengatakan model pembelajaran PBL hanya dapat terjadi jika guru mampu menciptakan lingkungan kelas yang terbuka dan membimbing pertukaran gagasan. Peran guru adalah sebagai pemberi rangsangan, pembimbing kegiatan peserta didik, dan penentu arah belajar yaitu suatu pola atau kerangka konseptual yang berisi prosedur sistematik dalam mengorganisasikan kegiatan pembelajaran untuk mencapai tujuan pembelajaran.

Fisika adalah pondasi penting dalam pengembangan sains dan teknologi. Tanpa adanya pondasi fisika yang kuat, keruntuhan akan perkembangan sains dan teknologi adalah suatu keniscayaan. Fisika adalah ilmu yang memelajari gejala alam berupa materi dan energi. Fisika mencakup kumpulan fakta, konsep, prinsip, hukum, porsulat, dan teori. Fisika sebagai salah satu cabang ilmu sains (IPA), memiliki 2 hal yang sangat penting yang saling terkait satu sama lain, yaitu fisika eksperimen dan fisika teori. Fisikawan memelajari fenomena-fenomena alam dan kemudian berusaha menemukan pola dan prinsip yang berlaku pada fenomena-fenomena tersebut yang berlaku pula pada ruang dan waktu yang berbeda.

Fisika merupakan ilmu yang berusaha memahami aturan-aturan alam yang begitu indah dan dengan rapih dapat dideskripsikan secara matematis (Mundilarto, 2002:4). Tinggi rendahnya kualitas penguasaan fisika tergantung dengan bagaimana proses pendidikan fisika berjalan dan bagaimana metoda belajar yang diterapkan oleh guru dalam kegiatan pembelajaran.

Fisika sebagai proses merupakan langkah-langkah yang harus ditempuh untuk memperoleh pengetahuan atau mencari penjelasan mengenai gejala-gejala alam. Melalui pendidikan fisika logika berpikir siswa menjadi sistematis terarah dalam memandang alam lingkungannya, mengidentifikasi masalah yang ada serta pemecahannya (Suastra, 2006). Dalam pengajaran sains, aspek proses ini muncul dalam bentuk kegiatan belajar mengajar.

Ada tidaknya aspek proses di dalam pengajaran sains dan proses ini berjalan sangat tergantung pada guru. Teori-teori dalam buku-buku fisika seharusnya diajarkan dengan membawa persoalannya dalam bentuk yang kontekstual dan akrab dengan siswa. Kemudian siswa dibimbing melakukan berbagai aktivitas melalui kegiatan penyelidikan. Hal ini membuat siswa akan lebih paham terhadap fenomenafenomena sains melalui pengalaman sensoris mereka, dibandingkan dengan hanya menjadi pendengar di depan kelas. Fisika sebagai sikap merupakan berbagai keyakinan, opini dan nilai-nilai yang harus dipertahankan oleh seorang ilmuwan khususnya ketika mencari atau mengembangkan pengetahuan baru, diantaranya tanggung jawab, rasa ingin tahu, disiplin, tekun dan terbuka terhadap pendapat orang lain. 
Sikap-sikap yang harus dimiliki disebut sebagai sikap ilmiah. Sikap dapat diklasifikasi ke dalam dua kelompok besar, yaitu seperangkat sikap yang bila diikuti akan membantu proses pemecahan masalah dan seperangkat sikap yang menekankan sikap tertentu terhadap sains yaitu sebagai suatu cara memandang dunia serta dapat berguna bagi pengembangan karier di masa depan.

Pada pembelajaran fisika, sering dijumpai pembelajaran tidak dilakukan sesuai dengan hakikatnya. Sering dijumpai pembelajaran fisika dilakukan hanya sekedar berlatih mengerjakan soal dan sekumpulan angka dengan rumus tertentu, tanpa mengetahui apa makna sebenarnya dibalik rumus dan angka-angka itu. Kondisi demikian akan membuat daya tangkap dan kemampuan siswa dalam meamknai konsep materi fisika menjadi rendah sehingga hasil belajar yang dicapai siswa juga rendah. Hal yang terkait dengan hasil belajar siswa pada mata pelajaran fisika dimana pembelajaran fisika yang dilaksanakan di kelas XI MIPA 2 pada semester Ganjil SMAnegeri 1 Ubud berdasarkan hasil tes awal yang dilakukan Peneliti nilai rata-rata yang dicapai siswa rendah/dibawah KKM yaitu : 53,2 dengan ketuntasan belajar mencapai $20 \%$. Kondsisi demikian perlu segera diatasi. Untuk itu melalui Penelitian Tindakan Kelas ini Peneliti berupaya melakukan perbaikan - perbaikan agar siswa dapat meningkatkan hasil belajarnya pada tingkat yang lebih baik melalui penerapan model pembelajaran Problem Based Learning.

Sehubungan dengan hal tersebut diatas, maka peneliti mengambil judul dalam Penelitian Tindakan Kelas ini adalah "Penerrapan Model Pembelajaran Problem Base Learning Untuk Meningkatkan Hasil Belajar Fisika Materi Suhu Dan Kalor Bagi Siswa Kelas XI MIPA 2 Semester Ganjil SMA Negeri 1 Ubud Tahun Pelajaran 2017/2018.

\section{Metode}

Penelitian ini adalah Penelitian Tindakan Kelas dan yang menjadi subjek penelitian adalah siswa kelas XI. MIPA 2 SMA Negeri 1 Ubud tahun pelajaran 2017/2018, dengan jumlah siswa adalah 35 orang. Waktu Penelitian mulai dari Perencanaan sampai dengan penulisan laporan hasil penelitian tersebut mulai dari bulan Juli s.d Desember 2017.

Metode Penelitian yang digunakan dalam Penelitian Tindakan Kelas ini adalah metode deskriptif analitis yaitu dengan mengumpulkan data, mendeskripsikan, mengolah, menganalisa, menafsirkan dan menyimpulkan data yang diperoleh melalui Penelitian Tindakan Kelas ini sehingga diperoleh gambaran yang sistematis. Dari hasil yang telah tekumpulkan dan diolah kemudian dijadikan bahan kajian dalam menyusun laporan hasil Penelitian Tindakan Kelas yang Peneliti lakukan.

Rancangan penelitian adalah pokok perencanaan yang bertujuan untuk membuat target yang hendak dicapai dalam penelitian secara keseluruhan berjalan dengan baik sesuai apa yang direncanakan atau dikehendaki sehingga proses dan tujuan dari penelitian tersebut dalam memecahkan masalah bisa berjalan dengan baik serta jelas dan terstruktur. Rancangan penelitian tindakan kelas di pusatkan pada situasi dalam proses social belajar di kelas berlangsung secara kolaborasi. Dalam pelaksanaan proses pembelajaran di kelas, mengacu pada rancangan dan program, bahwa rancangan penelitian ini dilakukan atas dasar empiris yang didukung program penelitian tindakan kelas.

Untuk mendapat gambaran yang lebih jelas tentang rancangan penelitian tersebut dapat dilihat bagan di bawah ini sebagai berikut : 


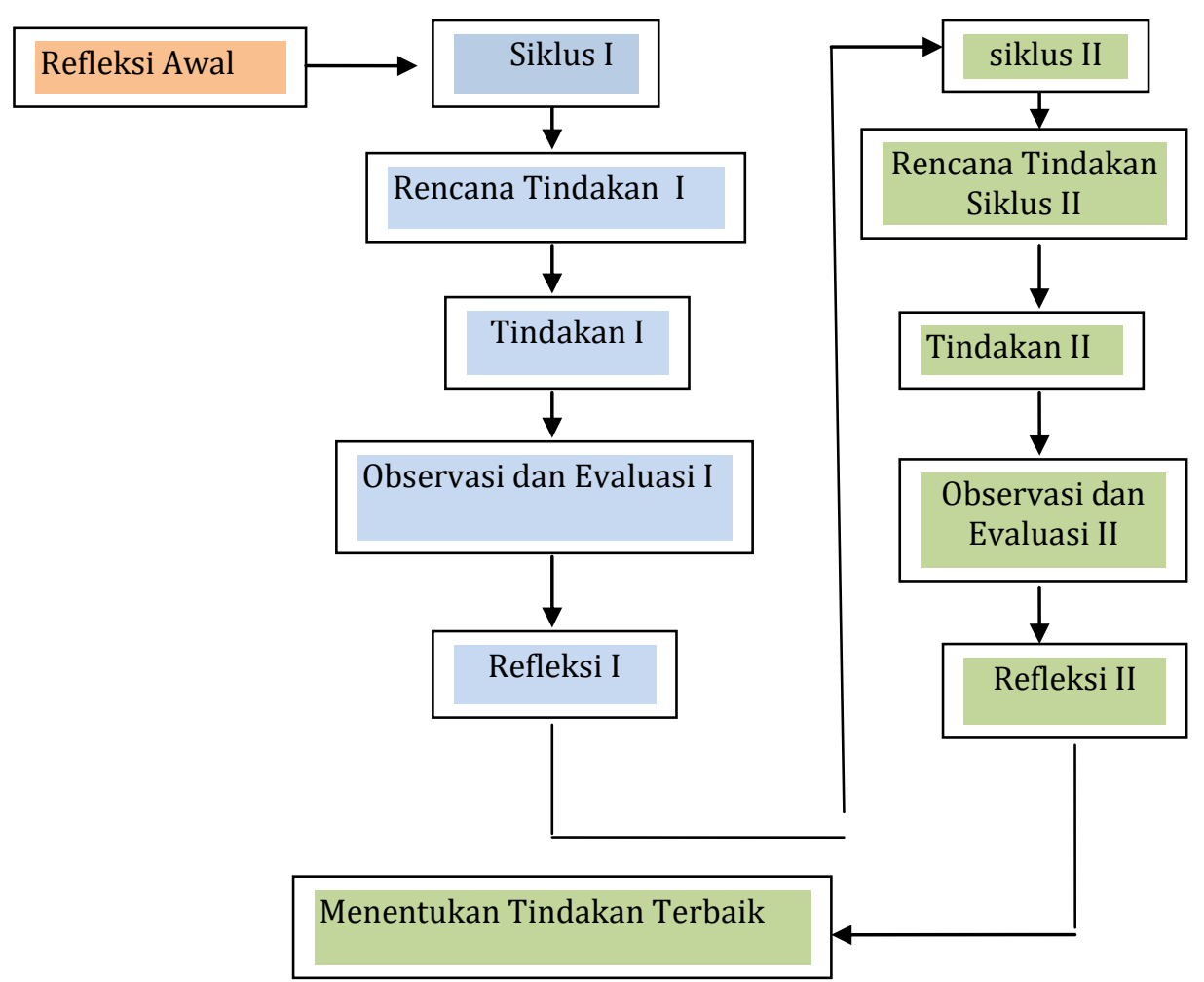

Gambar 1. Rancangan Penelitian

Sumber : Iskandar : 2012;114

Indikator kinerja yang ingin diperoleh dalam penelitian tindakan kelas ini adalah meningkatnya hasil belajar fisika pada siswa kelas XI MIPA 2 SMA Negeri 1 Ubud, setelah menerapkan model pembelajaran Problem Based Learning (PBL). Sebagai ukuran keberhasilan pelaksanaan penelitian tindakan kelas ini adalah siswa yang nilainya mencapai KKM yang telah ditentukan oleh sekolah untuk mata pelajaran fisika dan persentase ketuntasan siswa mencapai lebih dari 80\%. Jika hasil belum memuaskan akan dilakukan siklus II demikian seterusnya. Siklus akan berhenti jika hasil siswa sudah memenuhi KKM dan persentase ketuntasan yaitu 100\%.

\section{Hasil dan Pembahasan}

Hasil siklus I yang dapat Peneliti sajikan tersebut diatas adalah sebanyak 30 orang siswa (86\%) siswa yang mencapai ketuntasan belajar dan sebanyak 5 orang siswa (14\%) siswa yang belum mencapai ketuntasan belajar.

Jumlah rata-rata adalah 79. pada siklus I telah tertjadi peningkatan yang dicapai siswa dari Prasiklus. Namun masih ada siswa yang belum mencapai ketuntasan pad siklus I. Untuk itu perlu dilakukan perbaikan perbaikan pada siklus II .

Pada siklus I telah terjadi peningkatan hasil belajar yang dicapai siswa Peningkatan tersebut adalah :

1. Siswa telah menunjukkan kemampuan dalam menginterpretasikan materi fisika tentang kalor dan suhu dengan baik di siklus I .

2. Pemahaman siswa terhadap konsep-konsep materi suhu dan kalor pada mata pelajaran fisika telah meningkat dengan bukti nilai rata-rata yang dicapai siswa meningkat pada siklus I, namun demikian masih perlu bimbingan karena masih ada sebanyak 5 orang siswa yang belum mencapai ketuntasan belajar pada siklus I. ,

3. Siswa kelas XI MIPA 2 masih memerlukan tuntunan secara kontinu dalam meningkatkan hasil belajar fisika.

4. Model pembelajaran yang diterapkan dalam prasiklus terbukti mampu menstimulus siswa dan siswa nampak lebih termotivasi dalam belajar serta meningkatkan hasil belajarnya pada siklus I . 
Hasil yang telah dicapai oleh siswa pada prasiklus dan siklus I disajikan dalam bentuk gambar ( grafik), yang dapat disajikan dibawah ini.

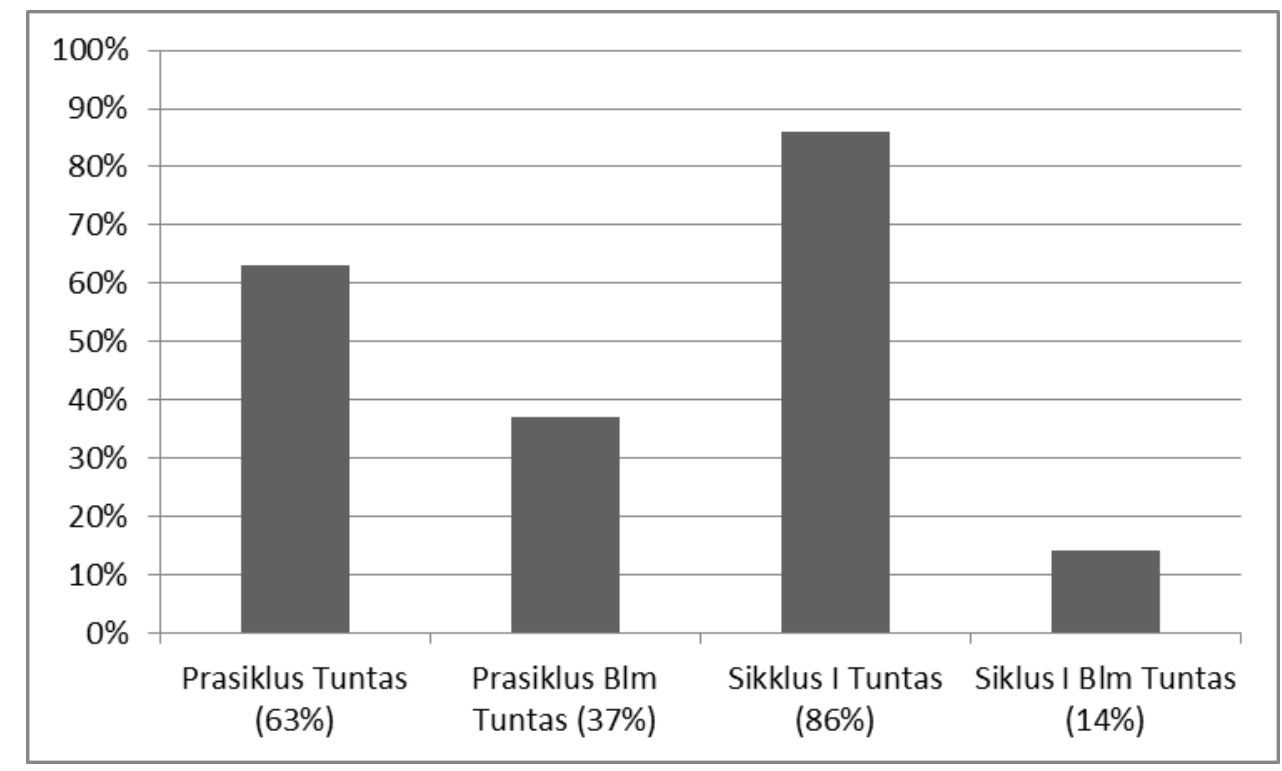

Gambar 2. Hasil Penelitian Siklus I

Keterangan :

1. Ketuntasan yang dicapai Siswa diPrasiklus

2. Siswa yang belum tuntas diPrasiklus $=63 \%$

3. Keberhasilan yang dicapai Siswa pada siklus $1=86 \%$

4. Siswa yang belum tuntas diSiklus I

$$
=37 \%
$$$$
=14 \%
$$

Berdasarkan hasil siklus I maka pada siklus II Peneliti melakukan perbaikan - perbaikan terhadap kelemahankelemahan yang dicapai pada siklus I. Pada siklus II, hasil pembelajaran mata pelajaran fisika dengan materi kalor dan suhu yang dicapai pada siklus I telah terjadi peningkatan sebanyak 23\%. Siswa telah menunjukkan kemampuannya dalam menginterpretasikan materi tentang suhu dan kalor pada siklus I dan hasilnya meningkat, sehingga ketuntasan belajar yang dicapai siswa di siklus I meningkat

Hasil siklus II yang dapat Peneliti sajikan adalah sebanyak 35 orang siswa $(100 \%)$ siswa yang mencapai ketuntasan belajar fisika dengan materi Suhu dan Kalor. Jumlah rata-rata adalah 82, dengan ketuntasan belajar mencapai $100 \%$. Pada siklus II semua siswa telah melaksanakan tugas pembelajaran fisika dengan baik. Siswa telah menunjukkan kemampuannya dengan maksimal dalam menginterpretasaikan materi pelajaran fisika tentang suhu dan kalor.

Keaktipan siswa pada siklus II dapat mendorong siswa untuk belajar lebih baik dan kosentrasi yang tinggi dalam upaya mencapai ketuntasan belajar yang maksimal. Peneliti bersama dengan observer memberikan bimbingan kepada siswa secara keseluruhan dimana semuanya mengikutinya dengan cermat.

Refleksi pada siklus II dilaksanakan dengan siswa dan juga dengan guru. Untuk guru bertujuan untuk memperoleh umpan balik terhadap pelaksanaan pembelajaran fisika, dan jika ada masukanmasukan dapat dijadikan sebagai bahan penyempurnaan pelaksanaan pembelajaran berikutnya. Untuk memperoleh gambaran dari keseluruhan hasil Penelitian Tindakan Kelas ini dapat disajikan dalam bentuk grafik pada halaman berikut ini.

Hasil belajar siklus II dapat disajikan pada gambar grafif dibawah ini. 


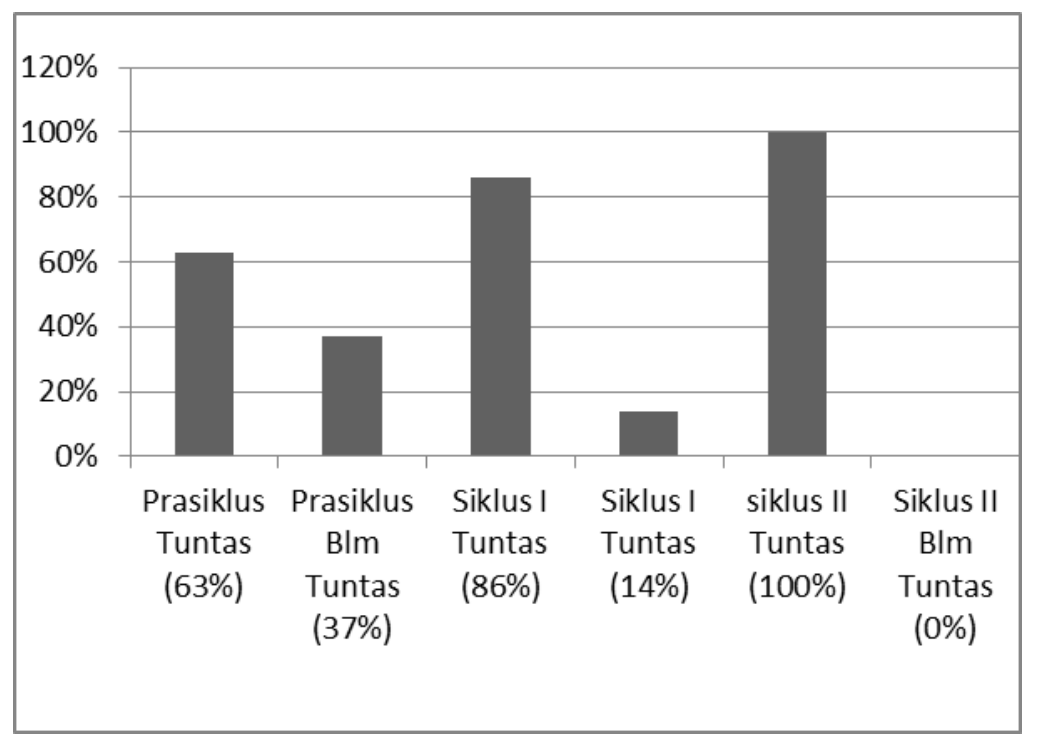

Gambar 3. Hasil Penelitian Siklus II

Keterangan :

1. Ketuntasan yang dicapai Siswa diPrasiklus

2. Siswa yang belum tuntas diPrasiklus

$=63 \%$

3. Ketuntasan yang dicapai Siswa pada siklus I

$=37 \%$

4. Siswa yang belum tuntas diSiklus I

5. Ketuntasan yang dicapai pada siklkus II

6. Siswa yang belum tuntas disiklus II

$=86 \%$

$=14 \%$

$=100 \%$

$=0 \%$

Dengan demikian pada siklus II tidak ada lagi siswa yang hasil belajar mata pelajaran fisika dibawah KKM atau tidak tuntas. Hal ini terbukti bahwa dengan penerapan model pembelajaran Problem Based Learning (PBL) siswa mampu menuntun siswa belajar dengan cermat dan mandiri dan cepat dapat menyimak materi mata pelajaran fisika tentang suhu dan kalor dengan tuntas.

Penelitian yang dilakukan oleh Novitri, dkk (2017) yang berjudul Penerapan Model Problem Based Learning Dengan Pendekatan Saintifik Untuk Meningkatkan Hasil Belajar Dan Kemampuan Pemecahan Masalah Siswa di Kelas VIII.8 SMPN 1 Kota Bengkulu. Hasil penelitian ini menunjukkan bahwa aktivitas belajar siswa pada siklus I dengan rata-rata skor sebesar 31 (kategori cukup), meningkat pada siklus II menjadi 34 (kategori baik), meningkat pada siklus III menjadi 37,5 (kategori baik) dan meningkat kembali pada siklus IV menjadi 39 (kategori baik). Hasil belajar kognitif siswa untuk siklus I diperoleh skor rata-rata 83,69 dengan ketuntasan belajar secara klasikal 60,86\%, meningkat pada siklus II menjadi 88,58 dengan ketuntasan belajar klasikal 78,26\%, meningkat pada siklus III menjadi 91,84 dengan ketuntasan belajar klasikal $82,60 \%$ dan meningkat kembali pada siklus IV menjadi 92,93 dengan ketuntasan belajar klasikal 86,95\%. Skor rata-rata kemampuan pemecahan masalah siswa pada siklus I sebesar 62,20; meningkat pada siklus II menjadi 72,46; meningkat pada siklus III menjadi 85,50 dan meningkat kembali pada siklus IV menjadi 90,94 . Berdasarkan hasil penelitian dapat disimpulkan bahwa penerapan model Problem Based Learning dengan pendekatan saintifik dapat meningkatkan aktivitas belajar, hasil belajar dan kemampuan pemecahan masalah siswa.

Selanjutnya penelitian yang dilakukan oleh Parasamya, dkk (2017) yang berjudul Upaya Peningkatan Hasil Belajar Fisika Siswa Melalui Penerapan Model Pembelajaran Problem Based Learning (PBL). Hasil penelitian menunjukkan bahwa (1) persentase ketuntasan individual secara keseluruhan meningkat dari siklus I sampai siklus III yaitu 69\%, 81\%, dan 94\%, dan persentase ketuntasan klasikal secara keseluruhan juga meningkat yaitu 50\%,60\%, dan 80\%. (2) adanya peningkatan aktivitas guru dan siswa selama proses pembelajaran. (3) terjadi peningkatan keterampilan guru dalam mengelola pembelajaran dari ketegori cukup baik menjadi baik. (4) respon siswa cenderung positif dimana $100 \%$ siswa menyatakan senang terhadap pembelajaran dengan menggunakan Model Pembelajaran Problem Based Learning (PBL) Berbasis Konstruktivisme ini. Dari penelitian ini dapat disimpulkan bahwa penerapan Model Pembelajaran Problem Based Learning (PBL) dapat meningkatkan hasil belajar fisika siswa kelas XI IPA di SMA Negeri 1 Darussalam pada materi Usaha dan Energi. 


\section{Simpulan dan Saran}

Berdasarkan penelitian yang telah dilakukan dapat disimpulkan bahwa penerapan model pembelajaran Problem Based Learning dalam pembelajaran fisika sangatlah tepat, dimana model pembelajaran Problem Based Learning mampu menuntun siswa lebih aktif dalam belajar. Hal ini ditunjukkan dari hasil belajar fisika siklus I adalah 79 dan meningkat pada siklus II menjadi 82.

Berdasarkan pengalaman Peneliti selama melaksanakan Penelitian Tindakan Kelas ini, saran yang dapat diajukan adalah sebagai berikut: 1) Dalam pembelajaran fisika penerapan model pembelajaran Problem Base Learning sangatlah tepat. Untuk itu disarankan kepada guru fisika yang mengajar di SMA negeri 1 Ubud dapat menerapkan model pembelajaran Problem Based Learning dalam mengajar dan guru harus selektif memilih strategi/metoda pembelajaran agar Kegiatan Belajar Mengajar fisika dapat berjalan secara efektif; 2) Disarankan perlunya pengembangan atau variasi dalam metoda mengajar pada mata pelajaran fisika, agar siswa tidak merasa jenuh dalam belajar fisika; 3) Kepada siswa disarankan jangan merasa takut dengan pelajaran fisika, karena jika siswa selalu merasa takut dan menganggap belajar fisika itu sulit maka akan susah mendapatkan hasil belajar yang baik. Cintailah mata pelajaran fisika karena sesungguhnya belajar fisika itu mengasikkan; 4) Bagi Sekolah disarankan dapat memberikan dukungan bagi guru-guru yang akan melaksanakan Penelitian Tindakan Kelas untuk peningkatan mutu pembelajaran Fisika.

\section{Daftar Rujukan}

Abdurrahman dan Bintoro. 2000. Memahami dan Menangani Siswa dengan Problema Belajar. Jakarta: Depdiknas.

Agung, Iskandar. 2012. Panduan Penelitian Tindakan Kelas bagi Guru. Jakarta: Bestari. Buana Murni.

Arikunto, Suharsimi. 1991. Pengelolaan Kelas dan Siswa, Sebuah Pendekatan Evaluatif. Bandung: Remaja Rosdakarya.

Fakhriyah, F. (2014). Penerapan Problem Based Learning dalam Upaya Mengembangkan Kemampuan Berpikir Kritis Mahasiswa. Jurnal Pendidikan IPA Indonesia, 3(1). Tersedia Pada: https://journal.unnes.ac.id/nju/index.php/jpii/article/view/2906/2934.

Firmansyah, A., Kosim, \& Ayub, S. 2015. Pengaruh Model Pembelajaran Berbasis Masalah dengan Metode Eksperimen pada Materi Cahaya terhadap Hasil Belajar Fisika Siswa Kelas VIII SMPN 2 Gunungsari Tahun Ajaran 2014/2015. Jurnal Pendidikan Fisika dan Teknologi, 1(3):154-159.

Hamalik, O. 2001. Proses Belajar Mengajar. Jakarta: PT Bumi Aksara.

Mundilarto. 2002. Kapita Selekta Pendidikan Fisika. Yogyakarta: Jurusan Pendidikan Fisika FMIPA UNY.

Nafiah, Yunin Nurun. 2014. Penerapan Model Problem-Based Learning untuk Meningkatkan Keterampilan Berpikir Kritis dan Hasil Belajar Siswa. Jurnal Pendidikan Vokasi, Vol 4, Nomor 1 Hal. 125-143. Tersedia Pada: https://journal.uny.ac.id/index.php/jpv/article/view/2540.

Novitri, Melin, dkk. 2017. Penerapan Model Problem Based Learning Dengan Pendekatan Saintifik Untuk Meningkatkan Hasil Belajar Dan Kemampuan Pemecahan Masalah Siswa di Kelas VIII.8 SMPN 1 Kota Bengkulu. E-Jurnal Inovasi dan Pembelajaran Fisika. Volume 4 Nomor 2.

Parasamya, Cut Eka, dkk. 2017. Upaya Peningkatan Hasil Belajar Fisika Siswa Melalui Penerapan Model Pembelajaran Problem Based Learning (PBL). E-Jurnal Ilmiah Mahasiswa Pendidikan Fisika Unsyah. Volume 2 Nomor 1.

Shofiyah, Noly, Fitria Eka Wulandari. 2018. Model Problem Based Learning (PBL) dalam Melatih Scientific Reasoning Siswa. JPPIPA (Jurnal Penelitian Pendidikan IPA), Vol. 3, No. 1, Hal. 33-38. Tersedia Pada: http://journal.unesa.ac.id/index.php/jppipa.

Slameto. 2010. Belajar dan Faktor-Faktor Yang Mempengaruhinya. Jakarta: Rineka Cipta. 
Suastra, I Wayan. 2006. Belajar dan Pembelajaran Sains (Buku Ajar). Singaraja: Undiksha.

Susilo, A.B., Wiyanti, \& Supartono. 2012. Model Pembelajaran IPA Berbasis Masalah untuk Meningkatkan Motivasi Belajar dan Berfikir Kritis Siswa SMP. Unnes Science Education Journal, 1(1):12-20.

Usman, Uzer, M. 2002. Menjadi Guru Profesional, Edisi kedua, cetakan ke empat belas. Bandung: PT Remaja Rosda Karya.

Wiseman, F.L. 1981. "The Teaching of College Chemistry: Role of Student Development Level". Journal ofChemical Education, 58(6) : 484-488.

Zuriah, N. 2003. Penelitian Tindakan dalam Bidang Pendidikan dan Sosial, Edisi pertama. Malang: Bayu Media Publishing. 